\title{
Az Egyesült Államok feJLődése A XXI. sZÁZADBAN Michael Beckley - „Rogue Superpower: Why This Could Be an Illiberal American Century.”
}

A színvonalas amerikai folyóiratban, a Foreign Affairsben megjelenö cikk az Egyesült Államok, és ezáltal a jelenleg fennálló liberális világkereskedelmi rendszer egy lehetséges, de igen nagy valószínüséggel bekövetkezö jövőképét mutatja be. A szerzö egy újabb blokkosodást vizionál, melynek fó okozója nem Kína vagy Oroszország, hanem maga az USA lesz. A publikáció ezen folyamat elemeit fejti ki részletesen, és akarva-akaratlanul jövöre vonatkozó kételyekkel telíti el az olvasót.

As President Donald Trump focuses on his main "America First” policy, the USA becomes more isolationist, leaving most of America-dependent countries with doubts regarding the future of the liberal international trade system. There aren't any signs of change: the U.S. population is getting more and more nationalits, while the technological progress and the rise of automation favor the isolation of the "Rogue Superpower" as well. The fate of the current world order heavily relies on the upcoming few years of American foreign policy. The research, written by Michael Beckley, focuses on analysing the possible future U.S. policy trends.

Mielőtt kiemelném a cikk tartalmi vonásait, érdemes egy rövid gondolatmenetben beszélni a címről. A „rogue” melléknévnek nincs egyértelmű magyar fordítása, az akadémiai szótárak is több köntösben értelmezik, több különböző árnyalatú (de egyértelműen negatív) jelentést tulajdonítanak a szónak, mely tükörfordításban értelmezhető gaznak, hitványnak, vagy szélhámosnak, csalónak. A címben szereplö „rogue America” kifejezés alighanem az ország „csaló” mivoltára utal: az Egyesült Államok elfordulni látszik attól az értékrendtől és világszintű gazdasági intézményrendszertől, amelyet a II. világháború után ő maga alakított ki. A XX. századból megismert Amerika átalakul - állítja a szerző - és ennek a hátulütőit legjobban az Egyesült Államoktól függő országok fogják megsínyleni.

Michael Beckley gondolatmenetét azon állításra építi fel, mely szerint a következő évtizedekben a világ legerősebb gazdasága az Egyesült Államok marad. Ezt a szerző két tényezővel kívánja bizonyítani: az elöregedésből következő népességfogyatkozással, valamint a teljes automati-

\footnotetext{
${ }^{1}$ Beckley, Michael (2020): „Rogue Superpower: Why This Could Be an Illiberal American Century.” Foreign Affairs, https://www.foreignaffairs.com/articles/united-states/2020-10-06/illiberal-american-centuryrogue-superpower
}

DOI: 10.14267/RETP2020.04.24 
záció felé hajló technológiai fejlődéssel, mely igen súlyos problémákhoz fog vezetni Kínában, Oroszországban, Európában, de hosszabb távon a most feltörekvő Indiában is. A cikk széles látóköre megmutatkozik a két probléma kifejtése kapcsán. Az imént felsorolt közép- és nagyhatalmak hadseregei mind igen nagymértékben támaszkodnak az emberi tényezőre (a védelemre költött kiadások 40-50\%-a személyi jellegü költség), míg az Egyesült Államok már olcsón és hatékonyan használja a legfejlettebb haditechnológiát, példának okáért megemlíthetjük a tömeges drónhasználatot. Az Amerikán kívüli közép- és nagyhatalmak hadserege tehát igencsak kiszolgáltatott annak az emberi erőforrásnak, amely államuk területén nemsokára drasztikusan lecsökken. A cikk becslései alapján Kína és Oroszország a következő néhány évtizedben komoly nyugdíjrendszer okozta válságokkal szembesül majd, éves GDP-jük akár felét is kénytelen lesznek visszaforgatni az ellátórendszerbe. Az USA ezzel szemben képes lesz a teljes, vagy a majdnem teljes önellátásra. Az ebben az országban leggyorsabban fejlődő automatizáció pótolni tudja majd a munkaerőhiányt, és a hadseregben is képes lesz elvégezni az emberek helyett a „piszkos munkát." A szerző úgy gondolja, hogy ezen folyamatok szinte biztosan bekövetkeznek, erre utaló jel például a gépek exponenciálisan növekvő tudása és dramatikusan csökkenő ára, vagy Oroszország és Kína korfája.

Jóval több nyitott kérdést tesz fel az olvasó számára azonban a publikáció az Egyesült Államok jövőbeli pozíciójával kapcsolatos alfejezete. Az írás a jövőbeli víziót a II. világháborút követően kialakult helyzetből vezeti le. A világrendet a két nagyhatalom, és az azok szövetségesei határozták meg. A nemzetközi intézmények csak az USA egyértelmü felülkerekedésével kezdtek el hatékonyan müködni, amerikai támogatással. Ennek következményeként az Egyesült Államok önmagát a liberális gazdaság és a demokratikus értékek védelmezőjeként tudta pozícionálni, és ez a nézet természetesen igen kedvező hatással volt az ország gazdaságára is: a dollármilliókkal megsegített országok kiszolgáltatott helyzetbe kerültek, kereskedelemre kényszerültek az Egyesült Âllamokkal, amely amellett, hogy uralta a nemzetközi áru- és szolgáltatásáramlást, meg tudta őrizni szuverenitásának jelentős részét is, ugyanis - ellentétben Oroszországgal - nem függött jelentősen egyetlen partnerétől sem, azok pótolhatóak voltak. Ez a függetlenségi törekvés erősödik fel napjainkban: az előrejelzések szerint például a technológiai fejlődés következtében Amerika képes lesz magát nagymértékben függetleníteni az olajtól.

A szerző hangsúlyozza, hogy ez a szeparálódási folyamat egyben politikai elzárkózást is hordoz az Egyesült Államok számára. Donald Trump 2016-os megválasztását nem a véletlennek köszönhetjük: a felmérések szerint a lakosság jelentős része pusztán az amerikai munkahelyek védelme és a bevándorlás megakadályozása miatt tartja fontosnak a külkereskedelmet. A nacionalizmus felerősödik - hangsúlyozza a cikk -, és nem csupán a jobboldali szavazók körében, hanem az USA teljes lakosságát érintően. Tehát ezen logika alapján a 2016-os Trump-kormány nemcsak a saját maga, hanem az ország lakossága által kívánt utat járta. A világsajtó részben csupán azért fogadta megdöbbenéssel az intézkedéseket, mert Donald Trump volt az első amerikai elnök, aki ezeket (szövetségek felbontása, partnerek kizárása) meg merte lépni. Az elmúlt négy év mintául szolgálhat az Egyesült Államok soron következő vezetéseinek. Az elemzés szerint ugyanis ez Amerika útja: a nagyhatalomnak egyre kevesebb stratégiai kereskedelmi partnerre van szüksége, föleg nem olyan szövetségesekre, melyek az elöregedés és a technológiai lemaradás következtében igen sokat fognak jelenlegi erejükből veszíteni. Az Egyesült Államok azonban természetesen szeretné megőrizni befolyási övezetét. A cikk erre vonatkozóan költségcsökkentési lehetőségeket lát: katonai osztagok helyett hamarosan elég lesz drónokat, robotokat tartani az amerikai támaszpontokon. 
Ahogy a bevezetésben említettem, a szerző úgy gondolja, hogy a világ ismét polarizálódni fog: az USA hatalmát látva Oroszország és Kína szövetséget köthet, vagy teljesen új összefonódások alakulhatnak ki, és ismét megnyílhat az egyes országok „hovatartozásának” kérdése. Egy ilyen folyamat akár az Európai Uniót is felszámolhatja, írja a kutató. Kína „Egy övezet, egy út" programja már egy ilyen irányba tett lépésnek is értékelhetö. Korábban érintettem, hogy a cikk a szovjet terjeszkedés sikertelenségét részben abban látja, hogy a nagyhatalom rá volt szorulva partnereinek erőforrásaira. Kína terjeszkedésével - immár saját véleményem szerint - hasonló a helyzet: a közel sem fogyasztásorientált, vagy legalábbis nyugati szemmel tekintve nem fogyasztásorientált népesség mellett az állam és a gazdasági szereplők rászorulnak a nagyarányú exportra, a külső piacok elérése és hozzáférhetősége létkérdés Kína számára. Az Egyesült Államok bezárkózása, illiberalizációja tehát végső soron hatalmas veszélyt jelent Kína számára is, és ehhez hozzájárul az ország hadseregének jósolt gyengülése is. Válaszlépésként a Kínai Népköztársaság láthatóan igyekszik a korábbinál jóval nagyobb befolyást szerezni a nemzetközi intézményekben: erre például szolgálhat a WHO koronavírus-válságra adott válasza, vagy a szervezet vezetőinek elmúlt hónapokban adott nyilatkozatai.

A cikk elgondolkodtatja az olvasót, mivel új nézőpontokból világítja meg világunk sajtóból ismert történéseit. Úgy gondolom, hogy a szerző széles perspektívából láttatja a XXI. századi kereskedelmi tendenciákat, a szövetségi rendszereket, valamint a Trump-kormányzatot. Néhány helyen éreztem csupán pontatlanságot, például Németországgal kapcsolatban jegyezte meg véleményem szerint hibásan - a cikk, hogy középkorú népessége hamarosan 17\%-kal csökkeni fog. A bevándorlás és az Európai Unión belüli mozgás (letelepedés) következtében ez a szám más felmérések alapján néhány évig alacsonyabb lesz. A folyamatokat azonban politikai nézetektől mentesen, tényszerűen, mégis izgalmasan láthatjuk. A cikk amellett, hogy fő szálán nem egy határozottan fényes jövőt fest le, felkínál alternatívákat is, melyek következtében a nemzetközi hangulat ismét enyhülhet, és a világrend is vehet olyan fordulatot a jövőben, melyből minden állam profitál. A szerző az ilyen alternatív megoldásokat az öregedő társadalmak erényeire építi: a békekeresés, mint általános, nemzetközi szinten is jellemző tulajdonság végigkísérheti a századot, emellett az automatizáció is segíthet kiváltani az öregedés által kieső munkaerőt, valamint termelést. Ahhoz azonban, hogy ez bekövetkezzen, az Egyesült Államoknak le kell mondania a teljes önérdekkövetésről (America First), illetve ezzel párhuzamosan aktív, partnereit védő külpolitikát kell folytatnia.

${ }^{2}$ egyetemi hallgató, Budapesti Corvinus Egyetem 